O024-3205-(94)E0051-R

\title{
THE INTESTINAL UPTAKE OF "ENZYMATICALLY-STABLE" PEPTIDE DRUGS IN RATS AS INFLUENCED BY D-GLUCOSE IN SITU
}

\author{
Zhenze Hu${ }^{1}$, Emmett G.C. Tse ${ }^{1}$, Donald C. Monkhouse ${ }^{2}$, \\ Choon K. Oh${ }^{2}$, and David Fleisher ${ }^{1 *}$ \\ ${ }^{1}$ Department of Pharmaceutics, College of Pharmacy \\ The University of Michigan, Ann Arbor, MI 48109-1065 \\ 2Department of Pharmaceutical Preclinical Research \\ SmithKline Beecham Pharmaceuticals, P.O. Box 1539 \\ King of Prussia, PA 19406-0939
}

(Received in final form April 5, 1994)

\begin{abstract}
Summary
In previous in situ and in vivo rat perfusion studies, the intestinal absorption of several low molecular weight drugs was increased by the presence of luminal Dglucose. The intent of this study was to determine the potential of this fed-state effect to improve the intestinal uptake of poorly permeable, small peptide and peptide-like drugs. Jejunal wall permeabilities ( $\left.\mathrm{Pw}^{*}\right)$ of di-(D-kyotorphin), tri(cephradine), hexa-(growth hormone releasing peptide, GHRP-6) and octa(octreotide, a somatostatin analogue) peptides and corresponding net water fluxes were determined in rats using an in situ single-pass perfusion technique. Glucose was shown to enhance the uptake of the smaller (di- and tri-) peptides but not the larger peptides despite the fact that glucose elicited a significant net water absorption with each of the four peptide drugs. It is concluded that glucose enhances jejunal permeabilities of smaller peptides by solvent drag and the enhancement is limited in situ by peptide molecular size. The studies with nonmetabolizable 3-Omethylglucose suggest that the augmentation of the proton gradient across the transmucosal membrane by glucose contributes to the carrier-mediated transport observed with the smaller peptides.
\end{abstract}

Key Words: intestinal absorption, peptides, glucose, solvent drag, microclimate $\mathrm{pH}$

The ongoing discovery of endogenous peptides with promising therapeutic potential necessitates the development of an efficient and practical mean of medicinal peptide delivery. Since indications for peptide drugs typically involve chronic pathology requiring long-term therapy, oral delivery is the first-choice route of administration. Unfortunately, the potential for successful oral treatment is often undermined by peptide instability towards gastrointestinal proteolytic enzymes and low peptide intestinal membrane permeability. These two limitations couple with hepatic clearance to restrict the extent of systemic delivery of an orally dosed peptide drug. To mitigate the stability problem, synthetic peptidic drugs such as octreotide (D-Phe-Cys-Phe-D-Trp-Lys-Thr-CysThrol), a somatostatin analogue, for treatment of neuroendocrine tumors (1), and growth hormone releasing peptide (His-D-Trp-Ala-Trp-D-Phe-Lys- $\mathrm{NH}_{2}$; GHRP-6) for pituitary dwarfism (2) have been developed with substantial resistance to proteolytic enzymes. This has been accomplished through cyclization (octreotide) and replacement of L-amino acids with D-amino acids (octreotide

\footnotetext{
* To whom correspondence should be addressed.
} 
and GHRP-6). Although the dramatically improved stability maximizes the luminal driving force for intestinal absorption, poor lipophilicity and/or significant aqueous hydrogen binding potential restrict intestinal membrane permeation (3). Furthermore, large molecular size (octreotide, octapeptide; GHRP-6, hexapeptide) precludes peptide uptake by the intestinal peptide carrier system $(4,5)$.

For oral administration of oligopeptides to result in therapeutic success, absorptionenhancing agents may provide an avenue to promote intestinal solute uptake. While some of these agents produce transient histological damage (6), a consideration of fed-state influences on intestinal absorption offers a class of permeability enhancing agents for which toxicity and safety concerns are minimal. Nutrients, such as D-glucose and amino acids, have been shown to enhance solute membrane permeability by induction of both solvent drag and structural alterations of tight junctions gating the paracellular pathway (7-11). An 11-amino acid hemepeptide (m.w. 1900) has been reported to permeate intestinal tight junctions in connection with glucose-elicited junctional dilation in vitro (12). The therapeutic potential of these findings has prompted an investigation into the nutrient-enhanced intestinal transport of relatively stable peptide drugs.

In this report, the effect of glucose on rat jejunal absorption of peptides was examined using an in situ single-pass perfusion technique. Large peptides, namely, GHRP-6 and octreotide, were chosen as candidates based on their relative stability to enzymatic degradation. D-kyotorphin and cephradine were also selected to determine the possible effect of glucose on the proton-gradientdriven intestinal absorption of a dipeptide drug and a tripeptide-like $B$-lactam antibiotic $(4,13)$ since the luminal presence of glucose augments the acidity of the microclimate layer in the small intestine (14-17). These smaller candidates are enzymatically stable and potential substrates for the proton gradient-driven mucosal peptide carrier. These four peptides should provide an adequate test of the glucose potential to enhance the small intestinal absorption of peptides as a function of peptide molecular size (Table I). The relative influences of glucose-induced solvent drag and glucoseenhanced transmucosal proton gradient on peptide transport were studied utilizing nonmetabolizable 3-O-methylglucose (3OMG) which does not alter the microclimate $\mathrm{pH}(14,17)$ but does stimulate water absorption to generate solvent drag (18). In addition, peptide stability against brush-border membrane enzymes and luminal enzymes was verified in vitro.

TABLE I

Structure and Molecular Weight of The Peptides Studied

\begin{tabular}{lcc}
\hline \multicolumn{1}{c}{ Peptide } & Structure & Mol. Weight \\
\hline Octreotide & (D-Phe)-Cys-Phe-(D-Trp)-Lys-Cys-Throl & 1020 \\
GHRP-6 & His-(D-Trp)-Ala-Trp-(D-Phe)-Lys-NH2 & 873 \\
Cephradine & Tripeptide-like & 349 \\
D-Kyotorphin & Tyr-(D-Arg) & 337 \\
\hline
\end{tabular}

\section{Materials and Methods}

GHRP-6 (SK\&F 110679) was provided by SmithKline Beecham Pharmaceuticals (King of Prussia, PA). Sandostatin (Octreotide Acetate for Injection, Sandoz Inc., East Hanover, NJ) was obtained from the University of Michigan Hospital Pharmacy. D-kyotorphin, cephradine, Dglucose, 3-O-methylglucose, D-mannitol, ethanesulfonic acid (Mes), N-[2-hydroxyethyl] piperazine-N'-[2-ethanesulfonic acid] (Hepes), [hydroxymethyl] aminomethane (Tris) and polyethylene glycol (PEG) 4000 were purchased from Sigma Chemical Co. (St. Louis, MO). ${ }^{14} \mathrm{C}-$ PEG 4000 was obtained from New England Nuclear (Boston, MA). All other chemicals were of reagent grade. 


\section{$\underline{\text { Stability of Peptides in Intestinal Brush-border Membranes }}$}

Intestinal brush-border membrane vesicles (BBMV) were prepared from rabbit small intestine according to the calcium precipitation method (19). The extent of purification of the brushborder membrane fraction was assessed by measuring alkaline phosphatase activity. The specific activity of this brush-border enzyme was enriched 18 -fold in the final preparation. The final BBMV preparation was suspended in $10 \mathrm{mM}$ Hepes/Tris buffer $(\mathrm{pH} 7.0)$ containing $100 \mathrm{mM}$ mannitol and $100 \mathrm{mM} \mathrm{KCl}$ and stored at $-80^{\circ} \mathrm{C}$ until use. Stability of peptides was studied by incubating $20 \mu \mathrm{L}$ of BBMV suspension (containing $25 \mu \mathrm{g}$ protein) with $80 \mu \mathrm{L}$ of peptide solution (100 $\mu \mathrm{M}$ GHRP-6, $5 \mu \mathrm{M}$ octreotide, $25 \mu \mathrm{M}$ D-kyotorphin, each in $10 \mathrm{mM}$ Mes buffer) at $\mathrm{pH} 6.5$ at $37^{\circ} \mathrm{C}$. At selected times, reaction was terminated by addition of $10 \mu \mathrm{L}$ of $10 \%$ trifluroacetic acid (TFA) solution. After centrifugation at $5000 \mathrm{rpm}$ (Microfuge E, Beckham Instruments, Palo Alto, CA), the supernatant was analyzed by HPLC.

\section{Stability of Peptides in Luminal Contents}

Luminal solution was obtained from single-pass perfusion of rat jejunum in situ. Exiting perfusate was collected from single-pass perfusion of $10 \mathrm{~cm}$ of jejunum with iso-osmotic Mes buffer (pH 6.5) carried out at $0.75 \mathrm{~mL} / \mathrm{min}$ over 20 minutes using a Harvard perfusion pump (Harvard Apparatus, South Natick, MA). Stability of peptides was tested by mixing $9.5 \mathrm{~mL}$ blank perfusate with $0.5 \mathrm{~mL}$ of each peptide solution (100 $\mu \mathrm{M}$ GHRP-6, $5 \mu \mathrm{M}$ octreotide, $25 \mu \mathrm{M} \mathrm{D}$ kyotorphin) and incubating the mixture at $37^{\circ} \mathrm{C}$. At selected times, $0.45 \mathrm{~mL}$ aliquot was mixed with $0.05 \mathrm{~mL}$ of $10 \%$ TFA solution and centrifuged at $5000 \mathrm{rpm}$; the supernatant was then assayed by HPLC.

\section{In Situ Single-Pass Jejunal Perfusion}

The in situ single-pass jejunal perfusion method was used without modification for octreotide, GHRP-6, D-kyotorphin and cephradine as previously described (20). Briefly, male Sprague Dawley white rats (weighing 300-350 g) were fasted overnight with free access to water. Following anesthesia with $4.5 \mathrm{~g} / \mathrm{Kg}$ body weight of urethane, the abdomen was opened by a midline longitudinal incision and a $10 \mathrm{~cm}$ jejunal segment (beginning $5 \mathrm{~cm}$ distal to the ligament of Trietz) was cannulated. Peptide solutions (100 $\mu \mathrm{M}$ GHRP-6, $5 \mu \mathrm{M}$ octreotide, $25 \mu \mathrm{M}$ Dkyotorphin and $2 \mathrm{mM}$ cephradine) were perfused at $0.2 \mathrm{~mL} / \mathrm{min}$ through the segment and output perfusate was collected every 10-minute interval for 90 minutes. Coperfusions of peptides with glucose and 3OMG were compared to that with mannitol (control). All perfusion solutions contained carbon 14-traced (specific activity $0.12 \mu \mathrm{Ci} / \mu \mathrm{mol}$ ) $0.01 \%$ PEG 4000 as a nonabsorbable marker. Perfusion solutions were made iso-osmotic with sodium chloride and buffered at $\mathrm{pH} 6.5$ with $10 \mathrm{mM}$ Mes solution.

Dimensionless wall permeabilities $\left(\mathrm{P}^{*}\right)$ were calculated from peptide input-to-output perfusate concentration ratios corrected for water volume change averaged over the last five $10-$ minute (steady-state) collection samples according to the previously published model (20). Net water fluxes normalized by the length of the perfused segment $(\mu \mathrm{L} / \mathrm{min}-\mathrm{cm})$ were determined by change in the concentration of PEG 4000 (10). It should be noted that in this paper, positive values of net water flux indicate net water absorption and negative values net water secretion.

\section{Analytical Methods}

Jejunal net water flux was determined by measurement of ${ }^{14} \mathrm{C}-\mathrm{PEG} 4000$. Half milliliter perfusate samples were mixed with $10 \mathrm{~mL}$ scintillation cocktail (EcoLite (+), ICN Chemical Inc., Costa Mesa, CA) and counted on a Beckman LS 9000 scintillation counter (Beckman Instruments Inc., Fullerton, CA).

Peptide concentrations in the perfusate and the vesicle samples were determined by high performance liquid chromatography methods. The instrumentation consisted of an auto injector (Waters, WISP Model 710B, Milford, MA), an absorbance detector (Kratos, Spectroflow Model 773, Ramsey, NJ) and a reverse-phase column (Lichrosorb RP-18, 10um, F.R. Germany). For 
GHRP-6, the mobile phase (30\% acetonitrile in $100 \mathrm{mM}$ ammonium phosphate- $5 \mathrm{mM}$ sodium hexanesulfonate- $0.28 \%$ triethylamine buffer, $\mathrm{pH} \mathrm{4)} \mathrm{flow} \mathrm{was} \mathrm{set} \mathrm{at} 1.5 \mathrm{~mL} / \mathrm{min}$ and eluent monitored at $210 \mathrm{~nm}$. For octreotide, the mobile phase $(40 \%$ acetonitrile in $10 \mathrm{mM}$ ammonium acetate buffer, $\mathrm{pH} \mathrm{4)} \mathrm{flow} \mathrm{was} \mathrm{set} \mathrm{at} 1.4 \mathrm{~mL} / \mathrm{min}$ and eluent monitored at $210 \mathrm{~nm}$. For Dkyotorphin, the mobile phase $(6 \%$ acetonitrile in $10 \mathrm{mM}$ ammonium acetate, $\mathrm{pH} 4$ ) flow was set at $1.4 \mathrm{~mL} / \mathrm{min}$ and eluent monitored at $274 \mathrm{~nm}$. For cephradine, the mobile phase (13\% acetonitrile in $20 \mathrm{mM}$ sodium phosphate buffer, $\mathrm{pH}$ 5) was set at $1.7 \mathrm{~mL} / \mathrm{min}$ and eluent monitored $262 \mathrm{~nm}$.

\section{$\underline{\text { Results }}$}

Stability of D-kyotorphin, GHRP-6 and octreotide in the jejunal perfusate (luminal enzymes) and the BBMV (mucosal membrane enzymes) are illustrated in Fig. 1. All three peptides tested were shown to remain more than $80 \%$ intact over an incubation period of at least one hour in the jejunal perfusate while their stability in the BBMV was relatively high and ranked at the order octreotide>GHRP-6>D-kyotorphin with half lives of 433, 200 and 107 minutes, respectively. Dkyotorphin was the least stable, but it was significantly more stable than L-kyotorphin (half life $<5$ minutes; data not shown). Cephradine has been previously demonstrated to be stable in the jejunal perfusate with a half life of about 100 minutes (21) while its stability in the BBMV was also adequate over the time course of the studies (22).
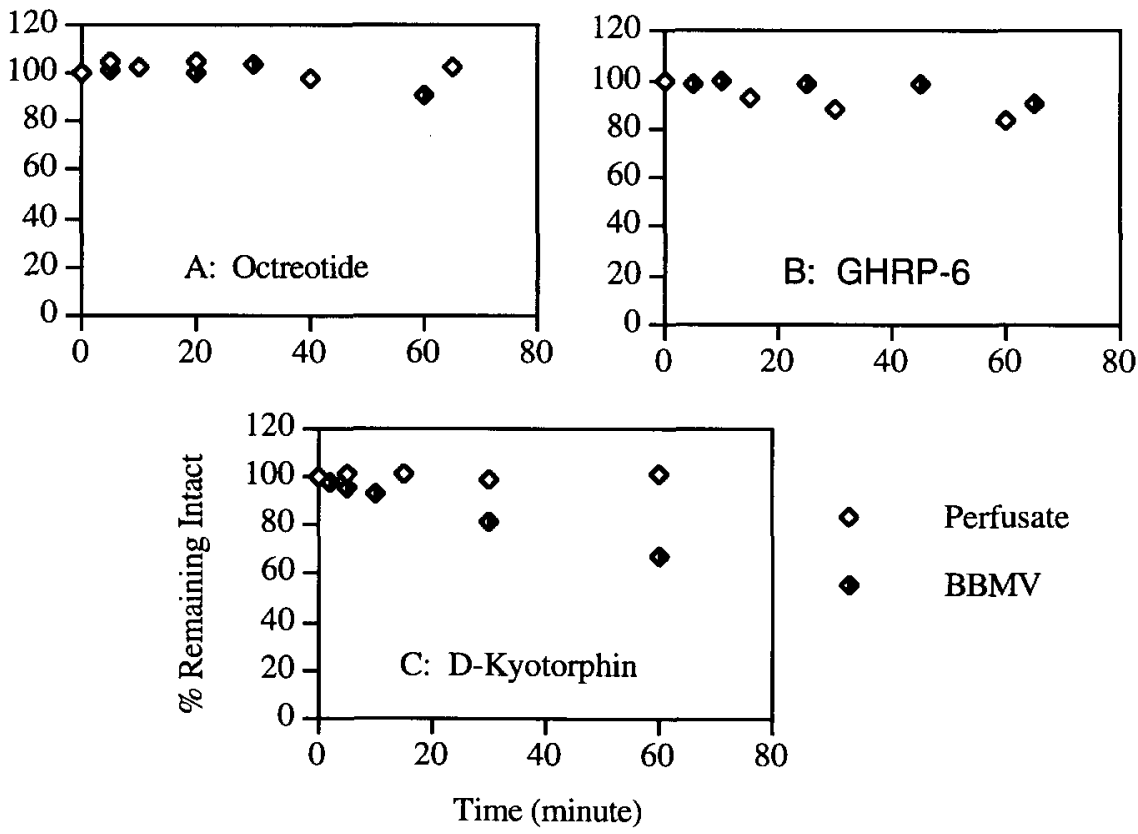

Fig. 1

Stability of peptides in the rat jejunal perfusate and the rabbit BBMV. The initial peptide concentrations in the perfusate and in the BBMV were 0.25 and $4 \mu \mathrm{M}$ for octreotide; 5 and $80 \mu \mathrm{M}$ for GHRP-6; 1.25 and $20 \mu \mathrm{M}$ for D-kyotorphin; respectively.

In rat jejunal perfusion experiments, steady-state dimensionless membrane permeabilities $\left(\mathrm{Pw}_{\mathrm{w}}^{*}\right)$ were obtained after 30 minutes of perfusion and reported as the mean value from $40-80$ minutes of perfusion. Permeabilities were determined in the presence of $112 \mathrm{mM}$ luminal glucose 
or $30 \mathrm{MG}$ versus $\mathrm{D}$-mannitol as a control. Net water fluxes (as $\mu \mathrm{L} / \mathrm{min}$ per $\mathrm{cm}$ of perfused intestinal length) were also measured and reported as positive values for net water absorption and negative values for net water secretion.

The influence of the coperfusion of $112 \mathrm{mM}$ glucose on the jejunal permeabilities of octreotide, GHRP-6, D-kyotorphin and cephradine and the net water fluxes at pH 6.5 is shown in Fig. 2. Compared to mannitol (control), glucose induced a significant net water absorption with each of the four peptides (lower panel). However, only the permeabilities of the smaller peptides, D-kyotorphin and cephradine, were significantly enhanced. It is noteworthy that glucose generated significantly less water absorption in the presence of luminal octreotide than in the absence of octreotide ( $\mathrm{p}<0.01 ;$ Student's t-test).
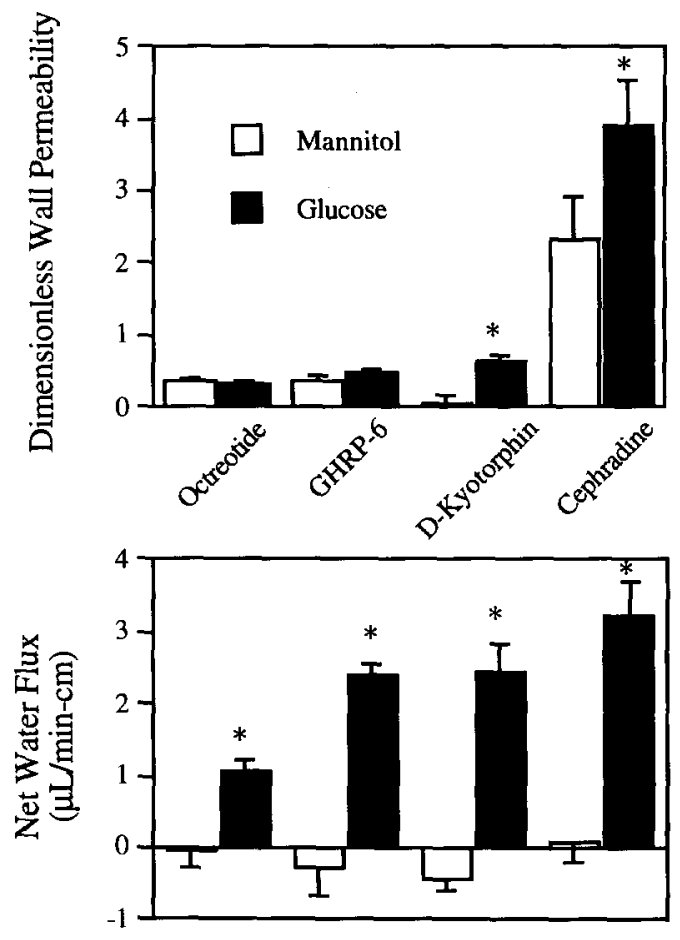

Fig. 2

Influence of the coperfusion of $112 \mathrm{mM}$ glucose on the jejunal dimensionless wall permeabilities $\left(\mathrm{Pw}^{*}\right)$ of the peptides (upper panel) and the net water fluxes (lower panel) at pH 6.5. Mannitol was used as control. The concentrations of octreotide, GHRP-6, D-kyotorphin and cephradine were $5 \mu \mathrm{M}, 100 \mu \mathrm{M}, 25 \mu \mathrm{M}$ and $2 \mathrm{mM}$, respectively. Results are expressed as the mean \pm standard error of three rats. * Statistically significant difference $(\mathrm{p}<0.05)$ based on Student's t-test as compared with each mannitol control.

The effect of glucose on the jejunal permeabilities of D-kyotorphin and cephradine was further compared to that of $30 \mathrm{OMG}$ which, unlike glucose, is nonmetabolizable inside the luminal cells and the results are presented in Table II. The permeabilities of D-kyotorphin and cephradine at $\mathrm{pH} 6.5$ were significantly increased to the same extent with $30 \mathrm{OG}$ as with glucose. This is consistent with increased net water absorption generated by either monosaccharide for both Dkyotorphin and cephradine. 
The effect of glucose (versus 3OMG) on cephradine permeability and net water flux depends on the perfusate $\mathrm{pH}$ (Table III). The results indicate that the enhancement of cephradine permeability at $\mathrm{pH} 7.5$ by $30 \mathrm{MG}$ ( $\mathrm{Pw}^{*}$ from 2.3 to 2.5 ) was less than that at $\mathrm{pH} 6.5$ ( $\mathrm{Pw} *$ from 2.3 to 4.0 ) whereas this $\mathrm{pH}$-dependence was not observed with glucose coperfusion. It was also found that there was a lack of $\mathrm{pH}$-dependence of monosaccharide-generated net water absorption for both glucose and 3OMG.

\section{TABLE II}

Comparison of glucose (metabolizable) versus 3OMG (nonmetabolizable) with regard to their influence on the jejunal dimensionless wall permeabilities $\left(\mathrm{Pw}^{*}\right)$ of $\mathrm{D}$ kyotorphin $(25 \mu \mathrm{M})$ and cephradine $(2 \mathrm{mM})$, and the net water fluxes at $\mathrm{pH} 6.5$.

\begin{tabular}{|c|c|c|c|c|c|c|}
\hline \multirow{2}{*}{$\begin{array}{l}\text { Peptide } \\
\text { Perfused }\end{array}$} & \multicolumn{3}{|c|}{$\begin{array}{l}\text { Dimensionless Wall Permeability } \\
\qquad\left(\mathrm{Pw}^{*}\right)\end{array}$} & \multicolumn{3}{|c|}{$\begin{array}{l}\text { Net Water Flux } \\
\qquad(\mu \mathrm{L} / \mathrm{min}-\mathrm{cm})\end{array}$} \\
\hline & Mannitol $^{\mathrm{a}}$ & Glucose & $30 \mathrm{OG}$ & Mannitol & Glucose & 3OMG \\
\hline D-Kyotorphin & $\begin{array}{l}0.059 \pm \\
0.035^{\mathrm{b}}\end{array}$ & $\begin{array}{l}0.617 \pm \\
0.102 * *\end{array}$ & $\begin{array}{l}0.393 \pm \\
0.065^{* *}\end{array}$ & $\begin{array}{c}-0.439 \pm \\
0.147\end{array}$ & $\begin{array}{l}2.456 \pm \\
0.375^{* *}\end{array}$ & $\begin{array}{l}1.885 \pm \\
0.313^{* *}\end{array}$ \\
\hline Cephradine & $\begin{array}{c}2.318 \pm \\
0.406\end{array}$ & $\begin{array}{l}3.914 \pm \\
0.603^{* *}\end{array}$ & $\begin{array}{l}3.980 \pm \\
0.273^{* *}\end{array}$ & $\begin{array}{c}0.085 \pm \\
0.269\end{array}$ & $\begin{array}{l}3.243 \pm \\
0.443^{* *}\end{array}$ & $\begin{array}{l}2.300 \pm \\
0.195^{* *}\end{array}$ \\
\hline ith each $\mathrm{c}$ & nannito & $n$ & 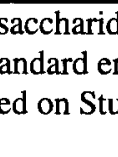 & $12 \mathrm{ml}$ & .05 & d \\
\hline
\end{tabular}

TABLE III

Effect of the perfusate $\mathrm{pH}$ on the jejunal dimensionless wall permeability $\left(\mathrm{Pw}^{*}\right)$ of cephradine $(2 \mathrm{mM})$ and the net water flux.

\begin{tabular}{|c|c|c|c|c|}
\hline \multirow{2}{*}{$\begin{array}{l}\text { Monosaccharide } \\
\text { Coperfused }^{\mathrm{a}}\end{array}$} & \multicolumn{2}{|c|}{$\begin{array}{l}\text { Dimensionless Wall Permeability } \\
\qquad\left(\mathrm{Pw}^{*}\right)\end{array}$} & \multicolumn{2}{|c|}{$\begin{array}{c}\text { Net Water Flux } \\
(\mu \mathrm{L} / \mathrm{min}-\mathrm{cm})\end{array}$} \\
\hline & $\mathrm{pH} 6.5$ & $\mathrm{pH} 7.5$ & pH 6.5 & $\mathrm{pH} 7.5$ \\
\hline Glucose & $\begin{array}{l}3.914 \pm \\
0.603^{\mathrm{b}}\end{array}$ & $\begin{array}{l}3.409 \pm \\
0.697\end{array}$ & $\begin{array}{l}3.243 \pm \\
0.443\end{array}$ & $\begin{array}{c}3.040 \pm \\
0.339\end{array}$ \\
\hline 3OMG & $\begin{array}{l}3.980 \pm \\
0.273\end{array}$ & $\begin{array}{l}2.486 \pm \\
0.440^{* *}\end{array}$ & $\begin{array}{c}2.300 \pm \\
0.195\end{array}$ & $\begin{array}{c}2.230 \pm \\
0.162\end{array}$ \\
\hline
\end{tabular}

a Concentration of the coperfused monosaccharides was $112 \mathrm{mM}$.

$\mathrm{b}$ Results are expressed as the mean \pm standard error of three rats.

** Statistically significant difference between $\mathrm{pH} 6.5$ and $\mathrm{pH} 7.5(\mathrm{p}<0.05)$ based on Student's t-test.

\section{Discussion}

In previous in situ $(9,10)$ and in vivo (11) studies, glucose was shown to increase the jejunal permeability of low molecular weight drugs (m.w. 150-350). This fed-state effect is of little in vivo consequence for lipophilic drugs whose absorption is dissolution-rate controlled; however, 
the systemic availability of small hydrophilic drugs may be improved when the oral absorption is limited by low membrane permeability. While small peptide drugs are in this latter physicochemical class, metabolism by gastrointestinal (GI) enzymes may further limit absorption potential. Fortunately, recent drug discovery efforts have produced peptide drugs that are significantly smaller (4-8 amino acids) yet relatively more stable to GI degradation than the endogenous parent peptides.

In an in vitro study, glucose-enhanced intestinal permeation of an undecapeptide (m.w. 1900 ) has been associated with a dilation of the tight junctions (12). The more recent in situ $(9,10)$ and in vivo (11) studies has further suggested the involvement of convective intestinal water flow (solvent drag) in glucose-enhanced uptake of small drug molecules. Therefore, this undertaken investigation was aimed to determine if luminal glucose would increase the intestinal absorption of stable peptide drugs in situ. Since the previous studies have indicated that glucose increases intestinal absorption of small solutes by solvent drag through dilated paracellular pathways, the dependence of this effect on molecular size was also investigated. The selection of stable peptide drug candidates included a dipeptide and a tripeptide-like B-lactam antibiotic which are potential substrates for the mucosal peptide carrier. The transport of small peptides by this carrier system is driven by a transmucosal proton gradient $(4,13)$; cellular glucose metabolism serves to enhance this gradient providing an additional glucose effect. In order to separate glucose-stimulated solvent drag from proton gradient effects, the influence of luminal $\mathrm{pH}$ and 3OMG, a nonmetabolizable and actively transported monosaccharide, on peptide transport was studied.

The stability studies on all four peptide drugs indicated that they were relatively stable in the jejunum (Fig. 1). Although there was a significant degree of degradation for D-kyotorphin in brush-border membrane vesicles, its stability was sufficient to allow an accurate estimation of jejunal permeability since the residence time of the peptide in the jejunal lumen in perfusion experiments was relatively short (about $6 \mathrm{~min}$ ) compared to its half life $(107 \mathrm{~min})$ so that a negligible amount of peptide underwent degradation.

The jejunal perfusion studies showed that the permeabilities of both cephradine and Dkyotorphin (m.w. about 350) were significantly increased by luminal glucose while this was not the case for octreotide or GHRP-6 (m.w. > 850) (Fig. 2). The corresponding increases in net water absorption by glucose suggest that the enhanced permeabilities of the small peptides result from the solvent drag effect (Fig. 2). One plausible hypothesis for the lack of glucose effect on the permeabilities of the large peptides is that sodium/glucose co-transport produces a dilation of the tight junction only large enough to admit the small peptides.

Baseline permeability of the dipeptide D-kyotorphin was surprisingly low (Fig. 2). It is possible that the $\mathrm{N}$-terminal $\mathrm{D}$-arginine renders $\mathrm{D}$-kyotorphin a poor dipeptide substrate for the mucosal peptide carrier (23-25). In addition, the low D-kyotorphin control permeability is consistent with paracellular uptake diminished by luminal D-kyotorphin generated water secretion (Fig. 2). The baseline permeability of the tripeptide-like cephradine was quite high under these perfusion conditions (Fig. 2) indicating that a substantial transport contribution is mediated by the mucosal peptide carrier.

The net water absorption generated by glucose was equivalent to $3 \mu \mathrm{L} / \mathrm{min}$-cm for each of the peptides except octreotide $(1 \mu \mathrm{L} / \mathrm{min}-\mathrm{cm})$ (Fig. 2$)$. The larger net water flux is equivalent to previous data obtained in rat jejunal perfusions of glucose both in situ $(9,10)$ and in vivo (11). The reduction in glucose-induced water absorption with octreotide perfusion is consistent with octreotide's capacity to diminish upper intestinal glucose absorption (26).

Glucose enhanced the permeability of both cephradine and D-kyotorphin, but a different extent of enhancement was observed (1.6 for cephradine and 0.56 for D-kyotorphin) (Table II). If the increase in permeability only represented glucose-stimulated solvent drag of the smaller peptides through paracellular pathways, a similar increase in dimensionless wall permeability would have Therefore, an investigation of the potential contribution of cellular glucose metabolism to favorably influence small peptide transport by enhancing the inwardly directed transmucosal proton gradient was carried out. The effect of enhanced transmucosal proton gradient can be separated from the 
solvent drag effect by utilizing nonmetabolizable 3OMG. $30 \mathrm{MG}$ is a substrate for the mucosal sodium/glucose cotransporter as well as the basolateral sodium-independent glucose carrier (27) and is capable of promoting net water absorption following transepithelial sodium movement similar to glucose (Table III). However, 3OMG will not lower microclimate $\mathrm{pH}$ through mucosal sodium/proton exchange as is observed subsequent to cellular glucose metabolism (14). From the studies, it was found that cephradine permeability from coperfusion with $30 \mathrm{OMG}$ at $\mathrm{pH} 7.5$ was significantly lower than that at $\mathrm{pH} 6.5$ while the permeability from coperfusion with glucose was not affected by the perfusate $\mathrm{pH}$ (Table III). This observation, which is not the result of solvent drag since net water absorption was not $\mathrm{pH}$-dependent for either monosaccharide (Table III), may be explained by the metabolizable glucose's capacity of maintaining a high proton gradient for carrier-mediated cephradine transport at higher luminal $\mathrm{pH}$ (7.5). The cephradine permeability results suggest that metabolic depression of microclimate $\mathrm{pH}$ contributes to the overall glucose effect on small intestinal peptide absorption.

In summary, poorly absorbed stable di-and tri-peptides are candidates for glucose-enhanced small intestinal absorption. The enhanced absorption of these small peptides appears to result from the glucose-elicited solvent drag effect and the microclimate $\mathrm{pH}$ effect. The small molecular size of the di- and tri-peptides provides a reflection coefficient less than one indicative of paracellular transport. The water absorption generated by sodium co-transported monosaccharides mediates convective drag of solute past expanded tight junctions (12). In addition, since the absorption of some di- and tri-peptides is mediated by the proton-coupled peptide carrier, glucose-generated lowering of microclimate $\mathrm{pH}$ elevates the mucosal proton gradient thus increasing the driving force for carrier-mediated transport. The solvent-drag effect and the microclimate $\mathrm{pH}$ effect should be of utility for enhancing the absorption of small peptides that are poor substrates for the small-intestinal peptide carrier. Small peptides, chemically modified for stability, and low molecular weight peptidomimetic solutes would fall into this class of solutes. However, these studies also suggest that there is not a significant potential for glucose enhancement of absorption of stable peptide drugs as large as hexapeptides. Peptides of this size are not substrates for the carrier and are sufficiently large to be totally reflected by paracellular size restriction. These latter results define the limitations of this fed-state effect for enhancing the absorption of small peptide drugs.

\section{Acknowledgments}

This work was supported by SmithKline Beecham Pharmaceuticals, NIH grant NS24616 and The Upjohn Research Endowment Fund for Pharmaceutical Research.

\section{$\underline{\text { References }}$}

1. G. WILLIAMS, J.V. ANDERSON, S.J. WILLIAMS and S.R. BLOOM, Acta Endocrin. (copenh) Suppl. 286 26-36 (1987).

2. C.Y. BOWERS, F.A. MOMANY, G.A. REYNOLDS and A. HONG, Endocrinology 114 1537-1545 (1984).

3. R.A. CONRADI, A.R. HILGERS, N.F.H. HO and P.S. BURTON, Pharm. Res. $\underline{8} 1453-$ 1460 (1991).

4. V. GANAPATHY and F.H. LEIBACH, Am. J. Physiol. 249 G153-160 (1985).

5. J.M. ADDISON, D. BURSTON, J.A. DALRYMPLE, D.M. MATHEWS, J.W. PAYNE, M.H. SLEISENGER and S.A. WILKINSON, Clin. Sci. Mol. Med. 49 313-322 (1975).

6. E.J.VAN HOOGDALEM, A.G. DEBOER and D.D BREIMER, Pharmac. Ther. 44 407443 (1989).

7. J.R. PAPPENHEIMER and K.Z. REISS, J. Memb. Biol. 100 123-136 (1987).

8. J.L. MADARA and J.R. PAPPENHEIMER, J. Memb. Biol. 100 149-164 (1987).

9. H.H. LU, G.L. AMIDON, P.J. SINKO and D. FLEISHER, AIDS $\underline{5}$ 907-908 (1992). 
10. H.H. LU, J.D. THOMAS and D. FLEISHER, J. Pharm. Sci. 81 21-25 (1992).

11. H.H. LU, J.D. THOMAS, J.J. TUKKER and D. FLEISHER, Pharm. Res. 9 894-900 (1992).

12. K. ATISOOK and J.L. MADARA, Gastroenterology 100 719-724 (1991).

13. W. KRAMER, C. DECHENT, F. GIRBIG, U. GUTJAHR and H. NEUBAUER, Biochim. Biophys. Acta 1030 41-49 (1990).

14. H. DANIEL and G. REHNER, J. Nutr. 116 768-777 (1986).

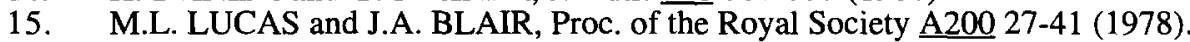

16. T. SHIMADA, J. Physiol. 392 113-127 (1987).

17. H.M. SAID, J.A. BLAIR, M.L. LUCAS and M.E. HILBURN, J. Lab. Clin. Med. 107 420-424 (1986).

18. H.H. LU, Ph.D. Thesis, 108-116, The University of Michigan.

19. A. TSUJI, T. TERASAKI, I. TAMAI and H. HIROOKA, J. Pharmacol. Exp. Ther. 241 594-600 (1987).

20. G.L. AMIDON, P.J. SINKO and D. FLEISHER, Pharm. Res. 5 651-654 (1988).

21. P.J.SINKO and G.L.AMIDON, Pharm. Res. $\underline{5}$ 645-650 (1988).

22. H. YUASA, G.L. AMIDON and D. FLEISHER, Pharm. Res. 10 400-404 (1993).

23. A.M. ASATOOR, A. CHADHA, M.D. MILNE and D.I. PROSSER, Clin. Sci. Mol. Med. 45 199-212 (1973).

24. S.A. ADIBI, Amino Acids: Metabolism and Medical Applications, G.L. Blackburn, J.P. Grants and V.R. Young (eds), 255-263, John Wright-PSG, Boston (1983)

25. J.M. ADDISON, D. BURSTON, J. PAYNE, S. WILKISON and D.M. MATTHEWS, Clin. Sci. Mol. Med. 49 305-312 (1975).

26. G.WILLIAMS, H.FUESSL, M.KRAENZLIN and S.R.BLOOM, Scand. J. Gastroenterol. 21(suppl. 119) 73-83 (1986).

27. U. HOPFER, Physiology of the Gastrointestinal Tract, 2nd edition, Leonard R. Johnson, 1499-1526, Raven Press, New York (1985). 